\title{
DIE OPKOMS EN DIE BETEKENIS VAN DIE OOSTE
}

\author{
Dr. G. D. Scholtz
}

\section{Die Ooste}

Die vraag ontstaan onmiddellik: wat word bedoel met die Ooste? Wanneer die saak ontleed word, blyk dit dat dit nie 'n vaste begrip is nie. Wanneer daar van die Ooste gepraat word, stel iemand hom op Europese standpunt. Alles wat ten ooste van Europa geleë is, is die Ooste. Dit beteken derhalwe dat die Ooste, Asië is. Waar begin Asië egter en waar eindig dit? Hierdie vraag is van sowel aardrykskundige as geskiedkundige belang.

Wanneer nou 'n kaart van die wêreld geraadpleeg word, word gevind dat daar 'n groot landmassa is wat hom uitstrek van die weste, d.w.s. van die Atlantiese Oseaan, tot die Stille Oseaan in die ooste. In die noorde word dit deur die Noordelike Yssee bespoel en in die suide deur die Indiese Oseaan. Op heeltemal arbitrêre wyse word hierdie landmassa in twee vastelande verdeel: Europa en Asië. As skeiding word aanvaar die Oeralgebergte, die Kaspiese See, die Kaukasusgebergte. Aan hierdie skeiding wat deur die aardrykskundiges getref word, het die geskiedenis hom nog nooit gesteur nie. Alexander die Grote het in die derde eeu voor Christus sy ryk tot aan die grens van Indië uitgebrei en die Griekse kultuur en beskawing in die verowerde gebied gevestig. Die grens van die Romeinse Ryk in die ooste was die Eufraat. Hierdie dele wat vandag tot Asië gereken word, is indertyd as deel van Europa beskou. En toe het 'n woestynvolk, die Arabiere, gekom en die Europeërs weer tot ten weste van die Middellandse See gedryf. So het dit tot vandag toe gebly.

Die aardrykskunde, soos dit die toneel van die geskiedenis is, het in werklikheid ' $n$ totaal ander verdeling van die groot landmassa gemaak as wat die aardrykskundiges gedoen het. Die bodem en die klimaat het saamgespan om van die landmassa ' $n$ tweeledige verdeling te maak. Al langs die rand van hierdie landmassa van die huidige Wes-Europa in die weste tot Japan in die ooste het daar in 'n betreklik smalle gordel die vernaamste beskawings van die mensdom ontstaan. Die res van die landmassa, wat eintlik die grootste deel is, het nooit ' $n$ beskawing van enige betekenis opgelewer nie en was 
die tuiste van die nomade, die ruitervolke, wat telkemale oor 'n tydperk van baie eeue oorvalle op die verskillende beskawings gedoen het.

Aan hicrdie toestand het daar 'n einde gekom sedert die Russe hulle in dic sewentiende eeu meester gemaak het van die hele gcbied waaruit die ruitervolke gekom het. Daarteenoor is die meerderheid van die rasse en volke wat in die beskawingsgordel woonagtig was, vandag nog daar. Die rasse en volke wat hulle in die westelikste deel van die beskawingsgordel gevestig het, die huidige Wes-Europa, het die skeppers geword van wat vandag as die Westerse kultuur en beskawing bekend staan. Dit is húlle wat van die res van die beskawingsgordel as die Ooste praat. Hierdie Ooste begin vir hulle aan die ander kant van die Middellandse See. Dit is hierdie deel van die wêreld wat die onderwerp van bespreking sal wees.

Drie besondere dele van die Ooste was tot dusver verantwoordelik vir die beskawings wat daar ontstaan het. Die eerste is Klein-Asië of soos dit ook genoem word, die Nabye Ooste. In die afgelope 6000 jaar was die Nabye Ooste die bakermat van 'n menigte beskawings wat gegroei, gebloei en gesterf het. Vandag word hier 'n beskawing aangetref wat sy inspirasie in die eerste plaas put uit die Islam, die godsdiens wat in die sewende eeu na Christus deur die bekende Mohammed gestig is. Die tweede is die skiereiland wat as Indië bekend staan. Hier word ' $n$ beskawing aangetref wat hoofsaaklik deur die Hindoe-godsdiens geïnspireer is. 'n Ander godsdiens wat op Indiese bodem ontstaan het, maar wat vandag omtrent nie meer daar geken word nie, is die Boeddhisme wat sy aanhangers vandag in Suidoos-Asië het. Die derde is die groot gebied wat as China bekend staan. Hier het nooit 'n eie godsdiens ontstaan nie. Tot onlangs toe egter was die lewensreëls wat deur Confucius enige eeue voor die geboorte van Christus opgestel is, die vorm waarin die Chinese beskawing gegiet was. Van China het die beskawing ook sy weg na die eilande gevind wat as Japan bekend staan.

\section{Die Weste en die Ooste}

Hier kan vanselfsprekend geen breedvoerige beskrywing gegee word van die weg wat die Westerse beskawing en dié van die Ooste opgegaan het nie. Tog sal dit nodig wees om heel kortliks op enkele verskille te wys. In die algemeen word 
'n mens deur die feit getref dat die Westerse beskawing veel dinamieser as die Oosterse beskawings was. 'n Besondere rede hiervoor moet ongetwyfeld in die ekonomiese omstandighede gesoek word. Terwyl die Weste vrywel niks opgelewer het waarvoor daar in die Ooste aanvraag was nie, was daar in die Ooste byna deurgaans allerlei produkte wat die Weste vir 'n beskaafde bestaan noodsaaklik geag het. Die gevolg hiervan was dat die Weste vir die grootste deel van die geskiedenis op soek na die Ooste was, maar dat die Ooste nooit na die Weste gaan soek het nie. So was dit vir die Romeine 'n uiters belangrike ontdekking dat hulle met behulp van die moessonwinde op die Indiese Oseaan na en van Indië kon seil. Daar het hulle edelgesteentes en allerlei tropiese produkte gaan haal. Dit was egter nie net Indië wat vir die Weste van ekonomiese betekenis was nie. Selfs die verre China was dit. Van daar het sy gekom wat vir die Weste so belangrik was. Hierdie sy is gebring deur karavane wat van China dwarsdeur die binneland van Asië tot aan die Swartsee of die Middellandse See gereis het oor 'n afstand van ruim 4000 myl en waarvan die politieke en ekonomiese betekenis vir die Weste nog onlangs op so 'n interessante wyse beskryf is deur die Franse historikus L. Boulnois en sy mooi boek La Route de la Soie (Die weg van sy).

Telkemale wanneer die verbinding met die Ooste om die een of ander rede onderbreek is, het die Weste ekonomies daaronder gely. Die laaste keer dat dit gebeur het, was toe die Turke, wat 'n ruitervolk uit die binneland van Asië was, daarin geslaag het om vrywel die hele Nabye Ooste te verower. Hierdie feit het die Weste op die rand van ekonomiese ondergang gebring. Alleen 'n wonderlike sameloop van omstandighede het die Weste gered. Die Wes-Europese volke het indertyd in ' $n$ belangrike oorgangstadium verkeer. Die Middeleeue was agter die rug en die tydperk wat vandag as die Renaissance bekend staan, het begin daag. Die mense van die Renaissance het hulle ook tot die beoefening van die wetenskap gewend. Dit sou later uitloop op wat bekend staan as die Wetenskaplike Rewolusie. Die beoefening van die wetenskap het die Westerse mens o.m. in staat gestel om die ruwe en stormagtige Atlantiese Oseaan te bevaar. Dit was een van die belangrikste keerpunte in die geskiedenis van WesEuropa, want nou was die volke in staat om óm die suidpunt van Afrika na die Ooste te seil. 
In sowel Indië as China het die kultuur en beskawing indertyd ' $n$ groot bloei beleef. Vir die beoefening van die wetenskap het die Oosterlinge egter weinig gevoel. Hulle het selfs met veragting daarop neergesien. Dit het hulle militêr en andersins weerloos teenoor die Westerling gemaak wat van sy toenemende beheersing van die natuur gebruik gemaak het om hom militêr sterk te maak. 'n Gebeurtenis wat vandag nouliks nog in die geskiedenisboeke vermeld word, het op treffende wyse aangetoon hoe sterk die materiële oorwig van die Westerling oor die Oosterling geword het. In 1505 het die Portugees Francisco d'Almeida aan die kus van Indië in 'n seeslag 'n groot oorwinning oor die Arabiese vloot behaal en sodoende die heerskappy van die Indiese Oseaan verkry. Selfs een van die kleinste en minder belangrike Westerse volke het oor soveel materiële krag beskik dat hy in staat was om 'n Oosterse volk op beslissende wyse te verslaan.

Op die Portugese het later ook die Britte, die Nederlanders en die Franse gevolg. Hul militêre mag was so groot dat dit hulle in staat gestel het om groot dele van die Ooste onder hulle heerskappy te stel. Brittanje het op stelselmatige wyse begin om Indië te verower. Nooit was die Indiërs in staat om doeltreffende weerstand te bied nie. Die Nederlanders het weer die Oos-Indiese eilande met hul ryk verskeidenheid van tropiese produkte onder hul gesag gestel.

Slegs twee Oosterse volke het in die sewentiende en agttiende eeue daarin geslaag om hulle vry van die Westerse aandag te hou. Hulle was China en Japan. Eintlik moet gesê word dat die materiële sterkte van die Westerse volke nog nie groot genoeg was om hierdie twee lande op doeltreffende wyse aan te durf nie. Hulle het ook verkies om so min moontlik met die Weste in aanraking te kom. Tiperend van die houding van die Chinese nog aan die einde van die agttiende eeu is ' $n$ brief wat die keiser Tsjieng-loen aan die Britse koning George III geskryf het na aanleiding van 'n versoek om diplomatieke en ekonomiese betrekkinge tussen hul twee lande aan te knoop. Die Chinese keiser het geskryf: „As to your entreaty to send one of your nationals to be accredited to my Celestial Court and te be in control of your country's trade with China, this request is contrary to all usage of my dynasty and cannot possible be entertained... Our ceremonies and code of laws differ so completely from your own that, even if your envoy were able to acquire the rudiments of our civilization, you 
could not possibly transplant our manners and customs to your alien soil... Swaying the wide world, I have but one aim in view, namely to maintain a perfect governance and to fulfil the duties of the State... I set no value on objects strange or ingenious, and have no use for your country's manufacturers" (Sir F. Whyte: China and Foreign Powers, Londen 1927, bylaag).

Japan was vir die Weste selfs nog ontoegankliker as China. Reeds vroeg in die sewentiende eeu het die Japanse volk tot die besluit gekom dat hy met die blanke Westerling absoluut niks te doen wil hê nie. Daarom is hulle verbied om hulle in Japan te kom vestig. Japan sou ook geen politieke of ekonomiese betrekkinge met 'n Westerse land onderhou nie. Japan het so 'n self opgelegde isolasie verkies bo enige verkeer met die Weste.

Op die Wetenskaplike Rewolusie in Wes-Europa het aan die einde van die agttiende eeu die Industriële Rewolusie gevolg. Deur die benutting van allerlei natuurkragte kon die Westerse volke hul materiële krag geweldig laat styg. Stoom en elektrisiteit, steenkool en staal - dit het nou die basis van die materiële sy van die Westerse kultuur en beskawing geword.

Die Weste het nou sy materiële krag aangewend om groot dele van die Ooste aan sy gesag te onderwerp en sy ekonomie te bou op wat die Ooste alles kon lewer. Met die aanbreek van die tweede helfte van die negentiende eeu was Indië reeds volledig aan Brittanje onderworpe. In 1875 kon daar selfs oorgegaan word om koningin Victoria van Brittanje tot keiserin van Indië uit te roep.

Nederland kon sy gesag uitbrei oor Oos-Indië van Sumatra in die weste tot Celebes in die ooste.

Frankryk het hom weer van Indo-China meester gemaak.

\section{Ontwaking en verset}

Die vraag het dus ontstaan of China en Japan andermaal die aanslae van die Weste sou kon weerstaan. Brittanje het reeds in 1842 in oorlog met China geraak en dit het tot gevolg gehad dat hy in besit van die eiland Hongkong, vlakby die Chinese kus, gekom het. In 1860 het Brittanje en Frankryk gesamentlik teen China uitgetrek en tot die hoofstad Peking deurgedring. Met die sluiting van die vrede het hulle vir hulle allerlei politieke en ekonomiese regte in China verseker. 
Japan is gedwing om sy self opgelegde isolasie te laat vaar. In 1853 het die Amerikaanse kommandeur Perry die kanonlope van sy oorlogskepe op die Japanse stad Jokohama gerig en geëis dat die Japanners hul land vir vreemdelinge sou oopstel. Die Japanners wat slegs nog met pyl en boog gewapen was, moes toegee. Japan sou voortaan oop wees. En toe het seker een van die merkwaardigste en snelste veranderings in die geskiedenis van die mensdom gebeur. In 1868 besluit Japan om met behoud van die geestelike aspek van sy kultuur en beskawing hom politiek en materieel heeltemal volgens Westerse voorbeeld in te rig. Manne word na die verskillende Wes-Europese lande gestuur om daar in die natuurwetenskappe te gaan studeer. Die Westerse tegniek word nageboots en heel spoedig vervaardig Japan sy eie masjiene, bou sy eie fabrieke en sy eie skepe. Ander Japanners mak weer 'n studie van die militêre stelsels van die verskillende Westerse volke en kom dan wat op hulle indruk gemaak het, in hul eie land toepas. Dit was die eerste teken van die feit dat die Ooste onder Westerse spoorslag aan die ontwaak was.

Die voorbeeld wat Japan so gestel het, het sy uitwerking op ander dele van die Ooste nie gemis nie, hoewel die reaksie in die verskillende dele nie dieselfde was nie. In die Nabye Ooste is die Arabiese volke, van wie 'n groot deel nog 'n nomadiese lewe voer, nog heeltemal tevrede om onder Turkse bestuur te staan. In Indië waar die Britte nog in 1857 'n opstand met militêre geweld gedemp het, begin 'n eerste roering op kulturele gebied plaas te vind. Hier was dit Vivekananda wat die eerste maal die mening uitspreek dat Indië hom ook na Westerse voorbeeld moet moderniseer. Van hom het die wekroep tot die Indiërs uitgegaan: „Make a European society with India's religion... Become an occidental of occidentals in your spirit of equality, freedom, work and energy and at the same time a Hindu to the very backbone in religious culture and insticts" (Jawaharlal Nehroe: The Discovery of India, New York 1947, bl. 339). Die weg wat so deur Vivekananda angewys was, is nog voor die einde van die negentiende ceu bewandel deur manne soos Tilak en Gokhale.

Die eerste tekens van verset teen die Weste in Indië was nog heeltemal vreedsaam. Heeltemal anders was dit met China gesteld. Met die opkoms van die ekonomiese imperialisme 
onder die moondhede van die Weste is daar begin om soveel meer aandag aan China te wy. Die een Westerse land na die ander het eise aan hom gestel, en omdat hy so totaal weerloos was, moes China dan toegee. Dit het onder die so trotse Chinese, wat vir die draers van ander beskawings so 'n diepe veragting koester omdat hulle niks anders as „barbare" is nie, 'n vurige haat teen alle blanke Westerlinge laat ontstaan. Brit, Duitser, Fransman en Rus - almal is gehaat. Dit het by sekere Chinese die vraag laat ontstaan of die voorbeeld van Japan nie gevolg moes word om hul land te moderniseer nie. 'n Eerste poging is reeds in 1898 gedoen, maar dit het misluk as gevolg van die teenstand van die keiserdinastie, die Mantsjoes. China het kort daarop een van die diepste vernederings in sy lang geskiedenis ondergaan. Die haat teen die vreemdelinge het in 1900 so groot geword dat 'n aansienlike aantal wat hulle daar bevind het, om die lewe gebring is. Dit was die sogenaamde Bokseropstand. Vreemde troepe het na Peking opgeruk. Die miljoene Chinese was egter nie by magte om enige teenstand te bied nie.

Hierdie vernedering het die strewe na modernisering nog meer lewe gegee. In 1911 het daar 'n rewolusie plaasgevind, die Mantsjoes is verjaag en 'n republiek uitgeroep. Die groot leier tot modernisering was nou dr. Soen Jat-sen, 'n man wat sy opvoeding in die Weste geniet het.

\section{Die eerste wêreldoorlog en daarna}

Sodanig was nou die toestand in die vernaamste lande van die Ooste, toe die Eerste Wêreldoorlog in 1914 begin het. Die oorlog was die uitvloeisel van die vrees en naywer van die Wes-Europese moondhede vir mekaar. Die strydende partye was vasbeslote om mekaar 'n groot nederlaag toe te dien. In hierdie stryd het hulle nie geskroom om ook van Oosterlinge gebruik te maak nie. Japan was in die Ooste die bondgenoot van Brittanje. Uit Indo-China en uit Indië het enige duisende soldate gekom om op Europese bodem aan die oorlog deel te neem. Brittanje het die Arabiere opgestook om teen Turkye, wat die bondgenoot van Duitsland was, in opstand te kom met die belofte dat hulle na die oorwinning vry sou word.

Die verskynsel dat die blanke Westerse volke mekaar met soveel verbittering beveg, het op miljoene Oosterlinge 'n diepe indruk gemaak. Dit was 'n ander indruk as dié wat hulle gekry het toe Japan enkele jare tevore daarin geslaag 
het om die groot Rusland ' $n$ nederlaag toe te dien. Toe was die indruk dat die blanke volke nie onoorwinlik was nie. In die Eerste Wêreldoorlog was die indruk dat die blanke volke ook in die Ooste die beginsels moet toepas wat hulle verkondig het, nl. die vryheid van alle volke.

$\mathrm{Na}$ die oorlog het Brittanje aan 'n deel van die Arabiese volke vryheid verleen. Dit het die Indiërs, die Ceylonese en die Birmane die vraag laat stel waarom aan hulle nie ook vryheid van die Britse gesag verleen word nie. Die man wat nou met 'n politieke aksie in Indië begin het en wat so een van die magtigste bewegings in die Ooste ontketen het, was Mohandas Ghandhi. Toe die Britte aan sy eis om selfbestuur vir Indië nie gehoor wou gee nie, het hy begin met 'n beweging van nie-geweld. Dit was 'n soort optrede waarteenoor die Britte volkome magteloos gestaan het, omdat hulle nie geweet het hoe om daarop te reageer nie. Bajonette en tronkstraf waarmee mense van die Weste so maklik vermurwe kan word, het op hierdie Oosterlinge nie die minste uitwerking gehad nie. Dit was 'n langsame manier om vryheid te verkry, en toe die Tweede Wêreldoorlog in 1939 begin het, het dit soms gelyk of Ghandhi selfs nog nie eens in sig van sy doel was nie.

Heeltemal anders het die toestand in die ander deel van die Ooste verloop. Hier het Japan nou die status van grootmoondheid geniet en kon hy saam met die ander vername moondhede van die wêreld deelneem aan die beslissing van die groot internasionale vraagstukke. Die imperialisme wat so 'n kenmerk van die Westerse moondhede was, het ook oor Japan vaardig geword. Hy het begin droom van 'n groot Japanse ryk in die Ooste, wat politiek en ekonomies aan hom verbind sou wees en waarvan hy alle ander volke sou uitsluit. Met sy manier van optrede het Japan nou Amerika en Brittanje sy vernaamste teenstanders gemaak.

Japan se taak om 'n groot koloniale ryk te skep is vir hom vergemaklik deur die chaos en verwarring wat daar in China geheers het. Om China te moderniseer en om dit sterk teen aanslae van buite te maak, was 'n haas onbegonne taak, en toe dr. Soen Jat-sen eindelik in 1925 oorlede is, was daar uiters min bereik. Sy opvolger, maarskalk Tsjiang Kaisjek, wat nog steeds in die lewe is, het as sy eerste doelwit gesien die vernietiging van alle Westerse belange in China. Om dit te bewerkstellig, het hy 'n stap gedoen wat hom op 
die duur suur sou bekom. Dit was om die hulp van die kommunistiese Rusland in te roep. Die Russe het so van die geleentheid gebruik gemaak om die eerste kommunistiese saad in die ontvanklike Chinese bodem te strooi.

Tsjiang Kai-sjek sou van omstreeks 1930 af met twee vyande te doen kry: Japan as buitelandse vyand en die Kommunisme, waarvan Mao Tse-toeng betreklik spoedig die vernaamste propageerder geword het, as binnelandse vyand. Dit behoort tot die tragiek van China dat Tsjiang Kai-sjek met twee vyande te doen gekry het en dat hy daarom voortdurend sy aandag van die een na die ander moes verskuif. In 1931 het Japan ' $n$ eerste maal toegeslaan en Mantsjoerye van China afgeneem. In 1934 het Tsjiang Kai-sjek 'n besliste poging aangewend om Mao Tse-toeng te vernietig, maar hy kon daar nie in slaag nie. Na seker een van die mees epiese togte wat 'n leërmag ooit in die geskiedenis van die mensdom uitgevoer het, het Mao Tse-toeng hom in die noordelike deel van China gaan vestig waar hy met 'n eie regering begin het. In 1937 het Japan die tweede maal tot die aanval oorgegaan. Militêr was China nouliks teen hom opgewasse en daarom het die strategie van Tsjiang Kai-sjek daarin bestaan om die binneland so diep moontlik in te trek ten einde die verbindingslinies van die Japanse magte so lank moontlik te rek.

\section{Na die Tweede Wêreldoorlog}

Slegs twintig jaar nadat die Eerste Wêreldoorlog ten einde gekom het, het die Tweede Wêreldoorlog begin. Hierdie keer was die Ooste selfs dieper in die stryd betrokke as die vorige keer. Japan het die bondgenoot van Duitsland geword en in 1941 met 'n veroweringstog begin wat sy magte tot vlakby Australië, tot die Indiese Oseaan en tot aan die grens van Indié gevoer het. $\mathrm{Hy}$ is alleen deur die snel wassende militêre sterkte van Amerika gestuit en teruggedring. In 1945 moes Japan kapituleer en van al sy verowerings afsien. Dit het gelyk of Japan nooit weer uit sy vernedering sou kon opstaan nie.

China wat so 'n harde afweerstryd teen Japan moes voer, het die bondgenoot van Amerika en Brittanje geword. Dit was met groot moeite en inspanning dat enige hulp aan hom verleen kon word. Met die kapitulasie van Japan was die Chinese leërmagte nog steeds in die veld. 
Indië wat nog steeds geen selfbestuur geniet het nie, is deur ' $n$ besluit van die Britse regering in 1939 deelgenoot aan die oorlog gemaak. Dit het Ghandhi, hierin bygestaan deur Jawaharlal Nehroe en ander manne, des te harder teen die Britse bestuur laat agiteer, wat veroorsaak het dat hulle die soveelste maal met die gevangenis kennis gemaak het.

In 1945 kon die wêreld weer rus geniet. Dit was egter 'n ontredderde wêreld en daarom was dit eenvoudig onmoontlik om na die vorige toestand van sake terug te keer. Dit was nou volkome duidelik dat daar in die opperheerskappy van die Weste oor sulke groot dele van die Ooste 'n drastiese verandering gekom het. Oral het die Oosterse volke geëis dat die Westerse gesag teruggetrek moes word. Hierdie eise van die Ooste is deur Amerika ondersteun. In die kort tydperk van 22 jaar wat sedert die Tweede Wêreldoorlog verstryk het, het die mensdom dan ook een van sy grootste veranderings van die afgelope paar eeue beleef. Die een na die ander het die koloniale ryke van die Wes-Europese moondhede begin verkrummel. Nederland moes reeds in 1945 onderhandelings met sekere Indonesiese leiers begin voer oor die eis van algehele onafhanklikheid. Onder die druk van Amerika moes Nederland daaraan voldoen. In 1949 het die onafhanklike staat Indonesië tot stand gekom. In 1947 het die Britse gesag uit Indië verdwyn toe twee state gestig is: Bharat (Indië) met 'n oorweënd Hindoe-bevolking en Pakistan met 'n oorweënd Mohammedaanse bevolking. Die Franse gesag in Indo-China is in 1954 beëindig nadat dit geblyk het dat dit onmoontlik was om die Kommuniste van Ho Tsji Minh te stuit.

Die rolle van China en Japan is as gevolg van die oorlog omgekeer. In 1949 het Mao Tse-toeng en sy Kommuniste daarin geslaag om Tsjiang Kai-sjek heeltemal uit China te verdryf. Hierdie oorwinning van die Kommuniste in China is tot dusver beslis die belangrikste politieke gebeurtenis sedert die einde van die oorlog. Hoe verder daar van die oorlog weg beweeg word, hoe duideliker word dit ook dat die bewindsaanvaarding van die Kommuniste in China 'n gebeurtenis is wat nog baie groot invloed op die toekoms gaan uitoefen. $\mathrm{Na}$ die voorbeeld van Rusland het die Chinese Kommuniste vrywel onmiddellik begin met 'n reeks vyfjaarplanne wat ten doel het om spierkrag aan die Chinese reus te verleen. Hoewel daar ook baie foute begaan is, staan dit nietemin vas dat China in die toekoms een van die vernaamste industriestate 
van die wêreld gaan word. Oor hierdie snelle opkoms van China het die Duitse geleerde dr. Wilhelm Fucks 'n boek geskryf onder die titel „Formeln zur Macht". Dit is seker een van die merkwaardigste en insiggewendste boeke van die afgelope paar jaar.

Japan het as gevolg van sy nederlaag sy posisie as een van die leidende politieke moondhede van die wêreld verloor. Hy is vandag die mindere van China. Daarteenoor het Japan - en dit waarskynlik tot verbasing van die res van die wêreld - daarin geslaag om een van die leidende moondhede op die gebied van die ekonomie te word. Hy word ten opsigte van ekonomiese produksie slegs deur Amerika en Rusland oortref. Hy het sedert die einde van die Tweede Wêreldoorlog reeds daarin geslaag om Wes-Duitsland en Brittanje verby te steek. Nietemin bly die lewe vir die ruim 100 miljoen inwoners van Japan besonder hard, want daar word groot inspanning van hulle geverg.

Japan is vandag 'n bondgenoot van sy voormalige vyand, Amerika en hy staan teenoor die twee vernaamste kommunistiese moondhede, China en Rusland. Deur middel van hul kernwapens is albei in staat om Japan uit te wis sonder dat hy in die vermoë is om terug te slaan. Dit veroorsaak dat die posisie van Japan in die wêreld besonder kwesbaar is.

\section{Kenmerke}

$\mathrm{Na}$ hierdie kort oorsig kan daar tans oorgegaan word tot 'n algemene ontleding van die toestand in soverre dit die Ooste raak. Dit kan bes gedoen word deur na die vernaamste kenmerke van die toestand te verwys.

'n Eerste kenmerk wat genoem moet word, is dat meer as die helfte van die mensdom vandag op die vasteland van Asië woon. En die totale bevolking van die wêreld is reeds op iets meer as 3,000 miljoen siele gestel. Dit spreek dus vanself dat in hierdie moderne wêreld wat in alle opsigte een geword het en waarin afstand geen rol meer speel nie, die lotgevalle van die Asiate op die verskillende terreine van die lewe nie deur die res van die mensdom geïgnoreer kan word nie. Dit is des te meer die geval omdat Asië tans ook die grootste bydrae lewer tot die so snel vermeerderende bevolking van die wêreld.

'n Tweede kenmerk van die hedendaagse Ooste is dat dit 
in belangrike opsigte nog heeltemal onontwikkeld en derhalwe agterlik is. Wanneer Japan nou vir 'n wyle uitgesluit word, kom 'n mens voor die feit te staan dat die wetenskap wat vandag so 'n uiters belangrike rol in die lewe van die Westerse volke speel, hom in groot dele van die Ooste nouliks nog laat gevoel. Daar gaan die lewe nog presies voort soos dit eeue gelede die geval was. Daarom sal dit van belang wees om kortliks na te gaan hoedanig die posisie tans in die verskillende dele van die Ooste is.

Hoewel die Nabye Ooste vandag die belangrikste leweransier van olie in die wêreld is, het 'n mens met die feit te doen dat hy ekonomies en andersins omtrent nog geen vordering sedert die einde van die Tweede Wêreldoorlog gemaak het nie. Die grootste deel van die bevolking daar is nog analfabete. Dit geld van alle lande en volke van Turkye in die weste tot Persië in die ooste.

Indië en Pakistan het reeds kort nadat hulle onafhanklik geword het, met prosesse van industrialisasie begin. Veral Indië het reeds 'n sekere mate van vordering gemaak deur die stigting van 'n staalindustrie. Tot 'n verhoging van die ekonomiese peil het dit egter nog geensins gelei nie en wel weens ' $\mathrm{n}$ besondere feit. Dit is die snelle vermeerdering van die bevolking. Op die oomblik word die bevolking van Indië jaarliks met sowat 10 miljoen siele vermeerder. Daarmee word die ekonomiese vordering elke keer heeltemal uitgewis.

Suidoos-Asië, wat 'n totale bevolking van ruim 100 miljoen siele het, moet nog die eerste stap in die rigting van 'n hoër ekonomiese peil doen. Dit geld ook vir Indonesië met sy bevolking van meer as 90 miljoen.

'n Derde kenmerk van die Ooste is daarom die skreiende armoede wat so 'n groot deel van die mensdom wat daar woonagtig is, moet verduur. Daar is al bereken dat meer as sestig persent van die totale mensdom aan ondervoeding ly. Die grootste deel van hulle is in die Ooste woonagtig.

\section{Verwestering, Nasionalisme en Kommunisme}

Hierdie wriemelende miljoene van die Ooste word tans voor een van die grootste uitdagings in die geskiedenis van die mensdom gestel. Hulle sal moet sorg dat hulle binne afsienbare tyd tot 'n hoër peil styg as wat tans die geval is. In die uitgawe van Januarie 1967 van die Amerikaanse tyd- 
skrif „Foreign Affairs" skryf die Oosterling Raul S. Manglapus: „Asia wants revolution; Asia needs revolution". Die Ooste moet ook die Wetenskaplike en die Industriële Rewolusie van die Weste ondergaan. Dit beteken dat die Ooste in geestelike opsig die Weste moet naboots soos Japan reeds gedoen het. Een van die grootste kenners van die hendendaagse Ooste, die Duitse skryfster Lily Abegg, verklaar dat die blanke volke van die Weste reeds hul stempel op die res van die mensdom afgedruk het. Die vernaamste faktor hierin is die wetenskap. Sy skryf: „Die naturwissenschaftliche und technische Revolution, die wir hervorgerufen haben, ist für die gesamte Menschheit nicht weniger umwälzend als es vor vielen Tausend Jahren die Entfachung des Feuers oder das Gieszen von Bronze gewesen ist ... Doch denken wir dabei unwillkürlich in erster Linie an unsere eigene Welt, an die europäische und amerikanische, wir übersehen dasz es nirgends mehr Völker gibt, denen wir das Gesetz des Handelens nicht aufgezwungen hätten. Denn wer nicht mitmacht, wer sich nicht modernisiert, der geht unter, kommt wieder unter Fremdherrschaft, wird wieder ausgebeutet oder gar ausgerottet... Heute werden wir freiwillig nachgeahmt - ïberall. Wir werden beneidet, bewundert und als Vorbild hingenommen" (Frankfurter Allgemeine Zeitung, 24.12.66).

Dit beteken dus dat die Ooste hom graag na Westerse voorbeeld wil instel. Die groot vraag is dus op welke wyse dit gedoen moet word. Moet dit gedoen word met volledige aflegging van alles wat as Oosters geld? Of moet dit gedoen word met behoud van allerlei Oosterse elemente soos Japan voorheen gedoen het? Oor hierdie vraag heers daar onder die miljoene Oosterlinge nog nie die minste sekerheid nie. Tiperend van die wyse waarop daar na 'n antwoord op die vraag gesoek word, is die titel wat die Duitse skrywer Walter Hildebrandt aan sy jongste boek gegee het: „Siegt Asien in Asien?" Soos Hildebrandt die saak insien, heers daar op die oomblik 'n stryd in Asië tussen die tradisionalisme, die nasionalisme en die Kommunisme om die voorrang te verkry. Wie in hierdie stryd gaan seëvier, is nog geensins 'n uitgemaakte saak nie. Hildebrandt is die mening toegedaan dat die toekoms van Asië beslis sal word deur die uitslag van die stryd tussen die nasionalisme en die Kommunisme.

Soos Napoleon Bonaparte aan die begin van die negentiende eeu by sekere Europese volke 'n gevoel van nasionalisme 
laat ontstaan het as gevolg van die smadelike nederlae wat hy hulle toegedien het, so het die Westerse verowering van groot dele van die Ooste ook daar 'n nasionale gevoel wakker geroep. Soos Karl Marx in die negentiende eeu die proletariërs van die verskillende Westerse volke opgeroep het om die Kommunisme as ideologie te anvaar, omdat dit hulle uit hul armoede sou verlos, so het die armoede wat so baie van die Oosterse volke tans teister, veroorsaak dat hulle hul ook na die Kommunisme gewend het.

Die Oosterse nasionalisme sien in die Weste, soos Lily Abegg verklaar het, sy voorbeeld. Nogtans verlang die Oosterse nasionalisme geen volledige verwestersing nie. Met die een hand hou dit aan die verlede, aan die tradisie vas, maar met die ander hand word daar uitgestrek na al die mooi en heerlike dinge wat die Weste kan bied om uit die armoede verlos te raak. 'n Mooi voorbeeld van die botsing wat daar soms tussen die tradisionalisme en die rasionalisme op Oosterse bodem kan ontstaan, is die stryd wat die regering van Indië moet voer om die volk so ver te kry dat daar in die koei geen heilige dier meer gesien sal word nie. Veel van die honger wat in Indië heers, word immers toegeskryf aan die wyse waarop daar geduld moet word dat koeie landerye opvreet sonder dat daarteen 'n vinger verroer mag word.

Die draers van die Kommunisme is arglistige mense. Volkome volgens die voorskrifte van Lenin is hulle bereid om van die nasionalisme 'n bondgenoot te maak, indien hulle daardeur hul uiteindelike doel soveel makliker kan bereik. Daarom word so dikwels gevind dat kommuniste in die Ooste hulle aan die hoof van die een of ander nasionale beweging stel. Dit is hulle wat ' $n$ beroep op die ontwakende gevoel van nasionalisme doen en wat dit dan wil gebruik om die beginsels van die Kommunisme toegepas te kry.

Dit is in werklikheid die nasionalisme van die 750 miljoen Chinese wat Mao Tse-toeng en sy kollegas wil aanwend om van hul land die leidende kommunistiese staat van die wêreld te maak. En juis omdat Rusland in die verlede hom so dikwels aan onreg teenoor China skuldig gemaak het, wend die Chinese hulle, ten spyte van die gemeenskaplike kommunistiese ideologie, met so 'n verskriklike felheid teen alles wat Russies is.

Die Ooste, d.w.s. van die Arabiese state in die weste tot China en Japan in die ooste, is vandag in aansienlike mate nasionaalbewus. Die hele Ooste is egter nog geensins Kom- 
munisties nie. Wanneer egter nou in aanmerking geneem word dat die deel van Rusland ten ooste van die Oeralgebergte en die hele China volgens die beginsels van die Kommunisme bestuur word, moet nogtans gekonstateer word dat, wat oppervlakte betref, die grootste deel van Asï reeds onder die gesag van die hamer en die sekel staan. Dit is 'n feit wat vir die res van die wêreld nie sonder betekenis is nie. Wanneer nou na die bevolking van Asië gekyk word, is die prent ook nie van die mooiste nie. Dan moet gekonstateer word dat sowat twee vyfdes van die bevolking reeds onder kommunistiese gesag verkeer. Die gevaar is groot dat in die toekoms nog meer mense van die Ooste agter die sogenaamde bamboesgordyn sal verdwyn.

Die Kommunisme is ' $n$ ideologie wat niks anders naas hom duld nie. Daarom is dit ook die groot vyand van die tradisionalisme. Oral in die Ooste streef die kommunistiese leiers daarna om 'n volkome breuk met die verlede van die volke waaroor hulle heerskappy voer, te bewerkstellig. So is Mao Tse-toeng tans besig om die invloed wat Confucius oor 'n tydperk van ruim 2300 jaar op die geestelike lewe van die Chinese volk uitgeoefen het, heeltemal te verbreek. In een van sy geskrifte het Mao Tse-toeng ronduit verklaar dat hy Confucius sedert sy jongelingsjare gehaat het. Wat die Chinese volk aan 'n eie kultuur en beskawing te danke het, was grootliks die werk van Confucius. Daar was in die Chinese geskiedenis dan ook geen groter geëerder naam nie as dié van Confucius. Of die kommuniste in hul doel sal slaag, staan te besien, want daar moet aanvaar word dat die invloed van Confucius diep reik.

Vir die mensdom as geheel is daar nouliks 'n groter gevaar as die Ooste in sy geheel tot die Kommunisme oorgaan. Indien dit gebeur, sal daar waarlik gewanhoop moet word aan die moontlikheid om hierdie ideologie ooit weer verwyder te kry. Op die vraag hoe die voortgang van die Kommunisme in die Ooste teengegaan moet word, het die Weste nog nie 'n definitiewe antwoord gevind nie. Die vernaamste Westerse lande meen dat dit die beste gedoen kan word deur grootskaalse ekonomiese hulpverlening en deur die intellektuele peil van die Oosterse volke te verhoog. Tot dusverre het hierdie beleid nouliks enige merkbare gevolge gehad. En tog dring die tyd. 


\section{Suid-Afrika en die Ooste}

Ten slotte nog 'n enkele gedagte oor die posisie van die Republiek van Suid-Afrika in verband met die Oosterse vraagstuk. Die Republiek is 'n voorpos van die Weste. Wanneer nou 'n kaart van die wêreld bestudeer word, is dit meteen duidelik dat Suid-Afrika veel nader an die Ooste as aan die Weste geleë is. Saam met die feit dat die Republiek op die vasteland van Afrika geleë is, is hierdie feit dat hy nader aan die Ooste as aan die Weste is, 'n saak wat sy posisie ten diepste raak. Tussen die Republiek en die Ooste lê die kleinste van die drie oseane. Hoeveel van die inwoners van die Republiek wat so graag aan die kus van die Indiese Oseaan met sy warm water gaan ontspan, dink ooit aan die feit dat aan die ander kant van die see daar miljoene Oosterlinge woonagtig is? Hoeveel dink verder aan die politieke, ekonomiese en maatskaplike omstandighede waarin hierdie mense verkeer? Tog gaan dit hier om feite wat vir die toekoms van die Republiek van lewensbelang is. Juis daarom is dit so diep tragies dat daar in die Republiek so min kennis bestaan van die mense van die Ooste, wat meer as die helfte van die mensdom uitmaak. Het dit nie meer as tyd geword dat hier in die Republiek aan die universiteite leerstoele vir die Oosterse kulture en geskiedenis gestig sal word nie? Inderdaad moet beweer word dat daar in min dele van die wêreld so ' $n$ intieme kennis van die Ooste behoort te wees as juis in die Republiek van Suid-Afrika. 


\title{
AFRIKA IN DIE WERELDPOLITIEK
}

\author{
Prof. J. H. Coetzee
}

Vir 'n duidelike begrip van die onderwerp is dit nodig om helderheid te verkry oor die betekenis wat geheg word aan die benaming Afrika en aan die uitdrukking wêreldpolitiek. Om met laasgenoemde te begin: vir ons Europa-sentries denkende Westerlinge beteken wêreldpolitiek in meer as een opsig die politieke geskiedenis en aktiwiteite van Europa of waarby Europa betrokke is, en dan ook nog allereers WesEuropa. Weliswaar bring ons historiese verbondenheid met die Christendom ' $n$ verbreding van die begrip ter insluiting van daardie wêrelddele en lande wat begrepe was in die ontplooiingsgeskiedenis van die Christendom. Op hierdie wyse begin Afrika se rol en plek in die wêreldpolitiek dan met sy aandeel in die politieke geskiedenis van die Nabye Ooste.

\section{Geografies}

Die Romeine het reeds die geografiese benaming "Afrika" in twee betekenisse gebruik: enersyds om die hele (grootliks onbekende) vasteland aan te dui maar terselfdertyd meer spesifiek om Noord-Afrika te designeer. Dit is nie te veel gesê wanneer beweer word dat tot en met die $15 \mathrm{e}$ eeu verwysings na Afrika feitlik uitsluitlik betrekking het op die noordelike en noordoostelike dele van hierdie kontinent nie. Dit is die gebiede wat in die Bybelse tye al vaagweg angedui is met die landsbenaminge soos Egipte, Punt, Kus, Cyrene ens. Soos die aardryk volgens die kennis van die mens groter geword het, veral deur die groot ontdekkingsreise sedert die $15 \mathrm{e}$ eeu en geïntensifiseer deur die koms van die $19 \mathrm{e}$ en $20 \mathrm{e}$ eeue met behulp van die nuwe vervoer- en kommunikasiemiddele, het Afrika ook in formaat toegeneem. Meer van Afrika het bekend geword aan Europeane en meer van dié geweste het betrokke geraak by al meer van die wêreld buite hom. By alles moet in gedagte gehou word dat Afrika polities, net soos histories, geografies, etnies en kultureel, geen monolitiese eenheid is nie maar ' $n$ groot verskeidenheid, selfs botsende, komponente huisves. Beperkte ruimte dwing hierdie bespreking tot veralgemenende terme en verwysings, maar dan altyd met die bestaande verskeidenheid in gedagte. 
Sy geografiese ligging bind Afrika uiteraard aan twee ander kontinente. Die landengte van Suez is soos die liggaamsvesels wat 'n Siamese tweeling onafskeidelik aanmekaar vasheg. Selfs die kunsmatige kanaaldeurgrawing kon dié verband nooit ten volle ophef nie, veral nie in sy historiese, kulturele en politieke sin en rol nie. Hierdie strokie woestyngrond het Afrika, meer besonder Noord-Afrika, aan die lotgevalle van claardie deel van Asië wat bekend staan as die Nabye Ooste, intiem vasgebind. Maar terselfdertyd het die Middellandse See i.p.v. 'n skeidende faktor te wees, Afrika - weer dieselfde Noord-Afrika - histories met Europa gekoppel.

Daar is weliswaar aanduidinge van regstreekse kontak tussen die ooskusstreke van die kontinent met die verdere Ooste t.w. Indië en China, maar afgesien van die tekens van handelskontakte weet ons so goed as niks van enige betrokkenheid van Afrika by die politieke lewe van daardie gewestes nie. Min of meer dieselfde geld van die handelsverband tussen Suid-Arabië en Oos-Afrika.

\section{Die oudheid en middeleeve}

Dat Egipte, die Nylland, van die Ou-Testamentiese tyd af dié verteenwoordigende staat en politieke gemeenskap in Afrika was, is 'n alte bekende feit. Daarmee hang saam sy sterk gerigtheid op die gebiede oos van Suez: Kanaän, Sirië, Babilonië e.d.m. Met die politiek van hierdie wêreld was Egiptiese Afrika ten nouste gemoeid: dan as bondgenoot of medestander van hierdie of daardie mag, dan weer as teenstander. In die politieke gebeure van daardie tyd wat die geskiedenis van Israel en daarmee ook dié van die vroeë Christendom so nou raak, neem Egipte 'n besondere plek in, dikwels as toevlugsoord en redder: vir Abraham, vir Jakob en sy seuns, vir die wordende Joodse volk, later vir die Christuskind en sy ouers. Maar Egipte is ook die twyfelagtige bondgenoot van Israel teen die opkomende noordelike magte: die gebroke rietstaf wat die hand wat daarop leun, deurboor, die aardse mag waarop Israel hoop in sy bedreiging van die kant van die Siriërs en die Babiloniërs nieteenstaande Jeremia se vermanings en profetiese voorsegginge.

Met die verskuiwing van die magswaartepunt na Meditterreense Europa - eers Griekeland en daarna Rome - draai Noord-Afrika sy blikrigting ook van oos na noord en raak 
hy sterk, indien nie oorwegend nie, betrokke by die politieke gebeure van die Europese staatswêreld. Die stad Alexandrië dra in sy naam die herinnering aan die feit dat die Macedoniër, Alexander die Grote, ook Egipte binne die grense van sy "wêreldryk" getrek het. Die Puniese oorloë, die stryd tussen die magte van Athene en Rome, kring uit tot in Noord-Afrika waar die mag van Karthago vernietig en die hele Maghreb, of Barbarye, onder Romeinse gesag gebring word. Noord-Afrika word die voorsiener van die koring wat benodig is deur Rome se brood-en-spelebeleid. Cleopatra, Julius Caesar en Pompeius word groot en beslissende name in die geskiedenis van Rome. Selfs na die Vaandaalse verowering van die Romeinse gesag in Afrika keer Noord-Afrika terug tot die kraal van die Oos-Romeinse ryk.

Waarskynlik Afrika se laaste belangrike verskyning in die Westerse internasionale politiek van hierdie tydvak lê in die Arabies-Islamse ekspansie van die $7 \mathrm{e}$ eeu af. Nieteenstaande wisseling van heersershuise bly Afrika weer eens verbonde aan die Nabye Oosterse politieke lewe selfs tot aan die begin van die 16e eeu, laastens as deel van die Ottomaanse ryk. 'n Totale afsluiting van Europa was dit egter nie, want as slagoffer en onderdaan van die Moslemse verowering en staatsvorming word hom 'n rol toegeken in die botsing tussen Christelike Wes-Europa en die Mohammedaanse wêreld. Hierdeur is etnies, kultureel en godsdienstig 'n nuwe band gelê wat tot op hede Noord-Afrika koppel aan die Nabye Ooste, sodat hy eintlik verskeur word tussen Afrika suid van die Sahara, Europa en Asië. Hierdie situasie lê aan die wortels van die huidige botsing tussen Israeli en Arabier.

Dit is opmerklik hoe Afrika toenemend 'n passiewe rol teenoor Europa en in die Europese politiek begin inneem het. Die inisiatief het van Griekeland en Rome en selfs van sy Oosterse bure uitgegaan met Afrika in die rol van verowerde, onderworpene en meeloper. Sy laaste aktiewe optrede in die sake van Europa was waarskynlik Karthago se verowering van Spanje in die derde eeu v.C. en Hannibal se opmars deur Europa na Rome. Hierdie passiewe deelname sou ook kenmerkend bly van sy rol in die tweede fase van sy internasionale politieke geskiedenis.

\section{Van die vyftiende eeu af}

'n Tweede era van Afrika se aandeel in die wêreldpolitiek 
begin eintlik met die soektog na 'n suidelike seeweg na Indië. Aanvanklik was Afrika, sover dit Europa betref, van geen ander betekenis nie as 'n lastige struikelblok waaromheen daar 'n omweg gesoek moes word. Op daardie tydstip was die strategiese betekenis van hierdie dwars-in-die-weg van die wêreldverkeer en die politieke implikasies daarvan nog nie baie duidelik nie. Europa se kontak met die donker landmassa is dan ook aanvanklik slegs op die periferie toegespits en slegs met die land eerder as met sy volke en hulle politieke lewe.

Gaandeweg brei die kontak weliswaar uit en veral in drie rigtings, t.w. handelsposte, verversingstasies vir die handelsvlote op hulle lang vaarte en beskermingsposte vir die handelsposte. Die werksaamhede van die handelsmaatskappye tesame met die toentertydse beleid van alleenhandel, die kompetisie om handelsbronne, waarin die slawehandel geen geringe rol gespeel het nie, betrek die een gebied na die ander in die politieke sfeer van die betrokke Europese state. Onder laasgenoemdes was Portugal, Nederland, Engeland en Frankryk veral belangrik en aktief met die Skandinawiese lande en Spanje ook af en toe in die prentjie en later ook met België, Italië en Duitsland op die toneel. Selfs Rusland sou onder die invloed van die Pan-Slawiese beweging ' $n$ keer belangstelling vir Afrika toon.

Op die periferale handelsondernemings volg die groot binnelandse ontdekkingsreise waarin Livingstone en Stanley besondere baanbrekerswerk met verreikende internasionale politieke gevolg sou verrig. Hulle togte met Livingstone se pleidooie om 'n pax Britannica en Stanley se optimistiese skildering van 200 miljoen inwoners van die Kongobekken wat luid roep om met Europese negosie bedek en van Europees vervaardigde goedere voorsien te word, was dan ook die voorlopers van die grootskeepse kolonisasie, die wedloop om Afrika. Afrika beheers op hierdie stadium die Europese politiek vir sover dit ' $n$ politieke mode word om 'n koloniale kleim in Afrika af te steek: wie dit nie kon of wou doen nie, het nouliks meegetel. Tot op groot hoogte is Frankryk en Duitsland gedwing tot deelname aan die koloniseringswedloop.

Soos verwag kan word, loop die mededinging uit op konflikte, bedreigings en bondgenootskappe. Die skepping van die Kongo-Vrystaat (1885) is die uitkoms van Leopold II se Internasionale Assosiasie vir die Ontdekking en Beskawing van Afrika. Europese en selfs V.S.A.belange in Afrika was die 
voorwerp van Bismarck se Berlynse Konferensie (1884-85) met al sy politiekery, verbonde en teenverbonde. Vryhandel en invloedsfere in Afrika word die twispunte en onderhandelingsbeginsels. Die Suezkanaal, geografies 'n Afrika-Arabieseaangeleentheid, word 'n gesamentlike ekonomiese en politieke onderneming van Europese moondhede, wat in een opsig lei tot samewerking tussen die belanghebbendes en kort daarna tot struweling tussen Frankryk en Engeland oor Egipte. Die Anglo-Portugese ooreenkoms van 1884 en die Engels-Duitse verstandhouding van 1890 en soveel ander is almal deur Afrika-belange geïnspireer, net soos die Brits-Duitse geskille oor Oos- en die Frans-Britse botsing oor Wes-Afrika.

Die nasleep van die slawehandel, nl. die humanisties gemotiveerde beëindiging daarvan en die eventuele vrystelling van die slawe bring Afrika ook weer binne die kader van semipolitieke aktiwiteite van Engeland en die V.S.A. deur die stigting van nedersettings vir hierdie bevrydes in Sierra Leone en Liberië. Die wyse van optrede deur die Britse regering teenoor slawe-eienaars in Suid-Afrika dra by tot die algemene politieke ontevredenheid wat kulmineer in die Groot Trek, 'n volksverhuising met uiters belangrike politieke gevolge, sommige waarvan sedert die einde van die Tweede Wêreldoorlog die aandag van die wêreldpolitiek uitermate in beslag geneem het.

Die voorgaande beklemtoon reeds die besondere posisie wat Suidelike Afrika in Afrika en m.b.t. hierdie vasteland se verhouding met Europa en die res van die wêreld die afgelope drie eeue ingeneem het. Hoe groter dié gedeelte van Afrika wat by die wêreldpolitiek betrokke geraak het, des te meer het die vereskeidenheid en die verskille in hierdie vasteland op die voorgrond getree. Almal het ongelukkig nie besondere aandag gegee of waarde geheg aan hierdie variante nie, 'n situasie wat hom besonders in die derde fase sou laat geld. Een van die omstandighede wat hom van die $18 \mathrm{e}$ eeu af veral sterk opgedring het, was die ontstaan van 'n nuwe etno-politieke gemeenskap aan die suidpunt van die Afrikakontinent. Dit het oorwegend sterk bande met Diets-Europa, veral met Nederland, besit en onderhou totdat dit van die negentiende eeu af mededingende kontak met Groot-Brittanje gemaak het. Ten tweede het dit die mees strategiese punt op die seeweg na die Ooste beset; en in die derde plek was dit die beskaafste staatsamelewing in die hele Afrika. Die Afrikagedeelte verste 
van Europa af sou gevolglik veel nouer betrekkinge met laasgenoemde onderhou as die veel nadere Noord-Afrika en sou daardeur ook ten nouste verstrengel raak in die politieke botsinge en aktiwiteite van die leidende Europese moondhede waaronder Engeland, Duitsland, Frankryk en Nederland. Die toedoen van hierdie magte het Suidelike Afrika twee keer aktief betrek by 'n wêreldoorlog van Europese oorsprong met ernstige binnelandse reperkussies en politieke botsinge in die Unie van Suid-Afrika.

Die kenmerkendste eienskap van Afrika se rol in die wêreldgebeure van die begin van die vyftiende tot die einde van die eerste helfte van die twintigste eeu was sy eintlik uitsluitlike betrokkenheid by die sake van die Weste, meer bepaald selfs van Wes-Europa en daarby sy oorwegend passiewe rol in dié verband. Die inisiatief, die doen- en dryfkrag was in die hande van die Europese state: hulle het verdrae gesluit, hulle het verdeel en saamgevoeg; hulle het gekoloniseer en geadministreer, hulle het proefnemings met beheer oor onderworpe volke geïnisieer, gewysig en deurgevoer, hulle het geëksploiteer, kapitaal belê en ontwikkelingsprojekte aangepak, werkers en soldate gerekruteer, skole en hospitale opgerig, ens., ens. Afgesien van sporadiese verset wat meestal met wapengeweld onderdruk is, was die Suide eintlik die enigste gebied wat, selfs nieteenstaande gewelddadige maatreëls, in 'n sekere mate saamgepraat het met die Europese magte, juis deur sy stryd om vryheid. Deur sy Europees georiënteerde beskawing het Suid-Afrika hom eintlik van die res van Afrika onderskei en kon hy met die Westerse volke saam gesels. Juis daarin sou sy latere omstrede posisie in die wêreldpolitiek gefundeer wees.

\section{$\mathrm{Na}$ die Tweede Wêreldoorlog}

Die derde fase van Afrika se betrokkenheid by die wêreldpolitiek breek aan met die beëindiging van die Tweede Wêreldoorlog, waarin hyself ook in meerdere of mindere mate 'n rol toebedeel is, nie deur eie keuse of inisiatief nie, maar deur die optrede van sy Europese metropole. Kenmerkend van die nuwe tydvak is die feit dat die hele Afrika nou betrek word by die politiek van die hele wêreld: Europa, Eur-Asië, die Nabye en die Verre Ooste, Indië, China en Japan, die V.S.A., Australië, Kanada en Latyns-Amerika. Dit is die tyd- 
perk van die ontvoogding van die kolonies wat Europese moondhede ongeveer 'n honderd jaar lank in Afrika beheer het. Soos dit teen die tweede helfte van die 19e eeu politieke mode in Europa was om kolonies in Afrika te bekom, was dit ná 1945 die toppunt van goeie staatsgedrag om vryheid aan hierdie kolonies te gee. Koloniale ryke wat met sorg, baie geld en strome bloed opgebou is, is nou veelal met onwaardige haas ontbind, ongeag die moontlikhede van die bevryde bevolkings om hulle ekonomiese selfstandigheid en politieke onafhanklikheid volgens die eise van die $20 \mathrm{e}$ eeu in die wêreldgemeenskap te handhaaf.

Hierdie proses beteken nie dat die eertydse koloniale moondhede en ander wat nie aan die wedloop deelgeneem het of nie daarin geslaag het nie, hulle hande heeltemal van Afrika afgetrek het en die volke daarvan totaal aan hulleself oorgelaat het nie. Eintlik is die wedloop van ongeveer 'n eeu gelede herhaal, net in 'n ander, miskien meer verfynde, vorm. Gewese koloniale magte het nou saam met nuwe belangstellendes soos die V.S.A., die Kommunistiese blok en die nuwe Asiatiese state ywerig, en nie altyd te realisties nie, begin meeding om die guns van die nuwe Afrikastate. Die motiewe hiervoor was ekonomies sowel as strategies, met lg. waarskynlik die belangrikste en gewigtigste motief. Hoe meer gespanne die verhoudinge tussen die groot politiek-militêre blokke, des te hoër het die Afrika-aandele in prys en waarde gestyg.

Dit is gevolglik ook nodig en nuttig om die nuwe Afrika se plek in die wêreldpolitiek te ontleed en te bepaal deur die aandag afwisselend te vestig op sy verhouding tot een van die onderskeie mededingende politieke groeperinge, hetsy as subjek of as objek. Weer eens moet waarskuwend daarop gewys word dat Afrika in hierdie proses nie as eenheid opgetree het nie. Sy verskeidenheid het telkens skerp na vore getree. Alhoewel die lyne nie altyd so skerp en duidelik getrek en die groeperinge nie onveranderd en belynd gehandhaaf is nie, moet ten minste met die volgende streeks-politieke onderskeidinge rekening gehou word: die Arabiese en oorwegend Moslemse Noord-Afrika; Wes-Afrika van die Negers, deels Moslems, deels Christene en gedeeltelik Animiste; Wes- en Sentraal-Afrika met die minderhede van Asiatiese en Europese immigrantegroepe onder die Bantoebevolkings; Suidelike Afrika met sy Bantoe-meerderhede te midde van allerlei ander bevolkingsgroepe soos die Khoisan-, die Kleurling- en die 
Asiate-minderhede en geregeer deur die getalsmindere maar beskawings-, ekonomiese en politiek sterkere blankes. Dan bly nog oor die reste van koloniale Afrika onder Portugese bewind, terwyl die tradisionele grense van Britse en Franse invloed nie heeltemal vervaag is nie en dikwels deur hierdie verdelings sny. Daarbinne kom ook nog voor groeperinge soos die Casablanca- en die Monrowia-groepe; Pafmecsa en die O.A.E.

Aan die begin van hierdie fase staan die verhouding AfrikaEuropa voorop. Met die beëindiging van die Tweede Wêreldoorlog was die hele Afrika, met uitsondering van Liberië en Ethiopië, onderhorige gebiede van Europese moondhede. Vanselfsprekend het die naoorlogse ontvoogdingsproses die aard van die eertydse verhoudinge wesentlik verander. Wat eers ' $n$ (Europees) bowe- en 'n (Afrika) onderskikkende posisie was, word nou 'n neweskikkende verhouding, ten minste in formele en staatsregtelike sin: soewereine state teenoor mekaar. In alle opsigte is die ou verhoudinge nie so maklik en geheel en al gewysig nie, want die herinneringe aan die koloniale verlede het 'n manier om nog lank te spook by die eertydse kolonies. Hulle gee veral blyk daarvan in ' $n$ uiterste fyngevoeligheid wat hulle status betref en 'n feitlik onbeskaamde hulpaanvraging op die veronderstelling dat die gewese koloniale heersers dit verskuldig is aan hulle voormalige kolonies. Die sterk emosionele element openbaar homself veral in die houding van die Afrikalede van die (Britse) Statebond m.b.t. beleid betreffende Portugal, Rhodesië en Suid-Afrika, waarin die ideologie van rassegelykheid en politieke erkenning bo alle oorwegings van ekonomiese stabiliteit, sosiologiese feitlikheid en etniese realiteite gestel word.

\section{Die Wes-Europese moondhede}

Europa moes uiteraard die grootse aanpassinge maak. Dit geld elk van die vroeëre koloniale state wat hulle invloedsfeer in Afrika wou behou, selfs in sterke kompetisie met vroeëre en nuwe belangstellendes, ter wille van prestige, grondstowwe en markte, maar ook ter wille van Wes-Europa gesamentlik. Noord-Afrika se strategiese belangrikheid vir Europa het deur die gebruik van moderne wapens eerder toe- as afgeneem. In vrede en oorlog verleen Afrika aan sy noordelike buurman ekonomiese ruimte: olie, landbou- en derhalwe voedselvoorrade tesame met lewensbelangrike minerale vir die nywer- 
heidsontwikkeling. Maar in oorlogstyd gee Afrika ook diepte aan Europa se verdediging. 'n Vriendskaplike Afrika dien tot beskerming van Navo se suidelike flank, terwyl bevriende hawens langs die suidelike roete na die Ooste, veral in geval van sluiting van die Suezkanaal, lewensbelangrik vir Europa is. Wie Noord-Afrika beheer, lê Europa streng aan bande. Dit is derhalwe te begrype dat Europa hoog sou bie om die guns van die nuwe Afrika. Uiteraard word die Europese belange nie so luicl verkondig in sy pogings om die koöperasie van die Afrikastate te bekom nie. Vir hierdie doel word gebruik gemaak van die metode om die voordele vir Afrika van ekonomiese en tegniese hulp, belydenis van samewerking tot ontwikkeling en stabilisasie en erkenning van die regmatige vryheidstrewe van hierdie volke te beklemtoon. Militêre hulp in die vorm van wapenvoorsiening en weermagsopleiding speel hierby 'n belangrike rol.

Gevolglik het nòg die gewese Franse nòg die gewese Britse kolonies en onderhorige gebiede hulle ná bevryding van die metropool onttrek. In die geval van vroeëre Britse Wes-, Oosen Sentraal-Afrika het die nuwe state lede van die Statebond geword en in die bepaalde situasie soveel afdingingsvermoë verkry dat hulle stem, in volume aangevul deur dié van die Asiatiese lede, dié van die ouere lidstate totaal oordreun het. Dit was hulle wat die Statebond oorreed het tot weiering van lidmaatskap aan die Republiek van Suid-Afrika, terwyl Wilson se Rhodesiese beleid in der waarheid deur die houding van hierdie state gedikteer word teen die prys, vir Brittanje, van ekonomiese kwellinge, verlies van markte en allerlei binnelandse politieke stremminge. Brittanje het self nog nie daarin geslaag om buite die swiep van die winde van verandering wat oor Afrika waai, te geraak nie. Miskien is die ironie van Macmillan se origens ware uitspraak oor die winde van verandering dat hy self nie die windsterkte en -rigting reg gepeil het voordat hy aan Suid-Afrika advies wou gee nie.

Die invloed van die vroeëre Frans-Afrika op die Franse binne- en buitelandse beleid was tot onlangs miskien minder opsigtelik en dramaties as in die geval van Engeland. Dit was nogtans kenbaar. Genl. De Gaulle het op 'n kritieke stadium in die Franse politieke geskiedenis die teuels oorgeneem, juis ten gevolge van 'n Afrika-insident. Hy was staatsman genoeg om die tekens van die tye te lees en om feitlik 'n regsomkeer in Frankryk se koloniale beleid van identifikasie met sy ,oor- 
sese provinsies" te bewerkstellig deur die Franse Unie te vervang deur die Franse Gemeenskap, 'n veel losser "statebond" waarin gesindheid en gemeenskaplikheid van belange die sementerende faktor is, eerder as die staatsregtelike en waarin die soewereiniteit van die jong state as uitdrukking van die nasionale besef van hulle volke volle erkenning geniet. De Gaulle het, teen die wense van die mense wat hom die presidentskap besorg het, die Algerynse knoop, Noord-Afrika se parallel van die Rhodesiese probleem, deurgehak deur aan Algerië 'n meerderheidsregering te gee. Hiermee het hy die goedgesindheid van Frans-Afrika - Wes, Ekwatoriaal en Noord - gewen en die voordeel van die Sahara-oliebronne en -kernkragtoetsterreine verseker. Tans dreig die posisie enigsins om De Gaulle se hand te forseer betreffende ' $n$ keuse tussen Israel en die Arabiese wêreld. Blyke van simpatie t.o.v. Israel kan hom die Arabiese gramskap op die hals haal en Frankryk se Saharabelange ontneem. In die lig hiervan moet sy versigtige beleid m.b.t. die Israel-Arabiese botsing geïnterpreteer word, waarin Frankryk blykbaar minder in die gedrang gebring is as die res van die Westerse magte. Dit is ook opmerklik dat Frankryk ook 'n eie weg bewandel wat die Republiek van Suid-Afrika betref en hom minder deur die ideologiese hartstog van die Afro-Asiatiese lande laat lei as deur Frankryk se ekonomiese belange en De Gaulle se beleid van 'n selfstandige Frankryk.

Hierdie gevalle toon hoe saamgesteld die Westerse situasie m.b.t. Afrika is. In hierdie konstellasie is selfs Europa geen eenheidskonsepsie nie. Frankryk volg grootliks sy eie weg soos ook blyk uit sy optrede teenoor die R.S.A. in die V.V. sowel as in die verkoop van wapentuig. Afgesien van Frankryk en Engeland en ongeag die Oos-Europese satellietstate van Rusland is daar ook nog Portugal wat in sy koloniale tradisie volhard. Hoewel lg. 'n koloniale beleid volg wat in die praktyk nie veel van dié van Frankryk verskil nie, het De Gaulle die veranderende omstandighede gouer gesnap en was hy waarskynlik in 'n gunstiger posisie as Salazar wat die bevryding van die oorsese gebiede en hulle vrye assosiasie met die eertydse metropool betref. Alhoewel Portugal hom nie laat voorskryf deur Angola en Mosambiek of deur ander Afrikastate en -organisasies nie, ervaar hy terdeë die gevolge van hulle optrede in die koste en die normale gevolge van oorlogvoering teen die rebellemagte. In die V.V. is hy feitlik heeltemal geïsoleerd, en uit daardie oord duur die druk en die betoning 
van vyandskap onophoudelik voort. Was dit nie vir Portugal se belangrike strategiese ligging vir Navo nie, sou hy vanweë sy Afrikabeleid waarskynlik nog veel meer geïsoleerd gewees het. Sy enigste bondgenote in Afrika is tans nog die Republiek van Suid-Afrika en die self ook geïsoleerde Rhodesië. Dit is een van die opvallende kenmerke van die wêreldpolitiek dat die R.S.A., Rhodesië en Portugal oor dieselfde kam geskeer word terwyl elkeen 'n ander beleid t.o.v. die nie-blankes volg.

\section{Die V.S.A.}

Vóór 1945 was Amerika se kontak met Afrika beperk tot enkele sporadiese en perifere gevalle. Een tiende van sy huidige bevolking is as slawe uit Afrika herkomstig. Partikuliere ondernemers het Wes-Afrikaanse handelsbelange gehad; eweso het Liberië deur partikuliere inisiatief hoewel met staatsimpatie as nedersetting vir bevryde slawe tot stand gekom. In die sewentigerjare van die $19 \mathrm{e}$ eeu het Stanley met sy soektog na Livingstone en die daaropvolgende ontdekkingstogte Afrika vir Amerika ontdek. Nogtans het Europa, by name koning Leopold II van België, meer voordeel getrek uit Stanley se werk as laasgenoemde se tuisland.

Die V.S.A., deur die Tweede Wêreldoorlog op die voorgrond gestoot as leier van die Westerse wêreld, betree die donker kontinent gedurende en veral ná die oorlog dus as 'n betreklike nuweling. Voorheen is Afrika-aangeleenthede deur sy eenheid vir die Nabye Ooste behartig. In 1943 is die eerste besondere Afrika-afdeling in voornoemde eenheid (Near Eastern Office) van die buitelandse dienste gestig en in 1958 word die eerste Assistent-Sekretaris vir Afrikasake benoem. Die volgende jaar het die Buro vir Afrikasake reeds 'n voltydse personeel van 70 gehad. Die motivering vir die V.S.A. se toenemende betrokkenheid by Afrika is veelvoudig. Amerikaanse bronne gee meestal die volgende aan: morele belang, ekonomiese oorweginge, die koue oorlog. Dieselfde bronne neig sterk daartoe om die hoofklem op die altruïstiese motiewe te laat val, sonder om noodwendig daarin te slaag om die aspekte van eiebelang daardeur volkome te kamoefleer, hoewel enkele openlik die egoïstiese erken.

Die morele dryfvere word verbind aan die herkoms van die Negerbevolking van die V.S.A., maar of dié vlag die lading volkome dek, bly 'n ope vraag. Weliswaar is die Amerikaners 
feitlik hartstogtelik besiel met 'n wêreldmissionêre roeping ten opsigte van die bevryding en demokratisering van alle minderbevoorregte en onvrye volke. Dit skemer bv. deur in 'n rede van mnr. Satterthwaite, die eerste Assistent-Sekretaris van die Bureau of African Affairs in 1959: „In sofar as we are able to set the good example by solving our own race relations problem, we will be better able to contribute to constructive and moderate solutions of similar problems in Africa". Hierdie uitspraak behels duidelik genoeg ook 'n ander aspek behalwe die humanitêre en morele bydrae van Amerika tot oplossing van Afrika se probleme, nl. die verbondenheid van sy rasseprobleem met dié van Afrika en van die wêreld. Hierin kom die kwessie van eiebelang dan ook weer na vore.

Dit is opmerklik dat een van Amerika se eerste groot naoorlogse projekte in Afrika 'n ekonomies-politieke opname van Tropiese Afrika was onder leiding van prof. Kimble. Amerika het tot die besef gekom van die lewensbelangrikheid van grondstowwe uit en markte in Afrika vir sy voortgesette ekonomiese en nywerheidsontwikkeling.

Staatsoptrede en politieke belangstelling is egter bo alles gemotiveer deur die internasionale situasie na beëindiging van die Tweede Wêreldoorlog. Die gewapende vrede of koue oorlog het 'n herskommeling van politieke en militêre magte teweeggebring. Oorlogsvennote het in twee kampe verdeel geraak en vyande het bondgenote geword. Amerika is op grond van sy ekonomiese en militêre mag voorgestoot as leidende moondheid van die Westerse blok, gekonfronteer deur Rusland as leier van die Oostelike en Kommunistiese magte. In hierdie verdeling het die blanke volke en die nie-blanke volke ook teenoor mekaar te staan gekom. Die vroeëre koloniale gebiede wat in die naoorlogse dekades en in aansluiting by die trusteeskapsbeleid van die V.V. onafhanklike state geword het, het grootliks verenig as 'n derde wêreld, die sg. neutralistiese of onverbonde mag. Hierby het Afrika hom gevoeg. Vir albei die ander magte, die Vrye Weste en die Sosialistiese Ooste was die vriendskap van hierdie derde mag lewensbelangrik.

Soos vir Europa is Afrika vir die V.S.A. in hierdie situasie van besondere strategiese belang. Die Tweede Wêreldoorlog het hierdie feit reeds onder Amerika se aandag gebring. In die daaropvolgende koue oorlog is die besef versterk dat Afrika binne die invloed- en vriendskapsfeer van die vyandelike blok, 
uiters gevaarlik kan wees. Derhalwe was die Egipties-Siriese verbroedering met die Sowjet vir die V.S.A. reeds 'n geweldige skok. Sy optrede teenoor Engeland en Frankryk oor die Nabye Ooste-kwessie (1956) moet dan ook gesien word as 'n poging om Egiptiese vriendskap, en daarmee dié van die Afro-Arabiere, te herwin nadat hy sy hulp vir die bou van die Aswandam onttrek en daarmee sy invloed onder die Afro-Arabiere verswak het. Volgens amptelike verklarings is die hulp onttrek vanweë die V.S.A. se twyfel oor die ekonomiese meriete van die onderneming, maar die klaarblyklike rede was daarin geleë dat Egipte na die Kommunistiese blok se kant beweeg het.

In sy wêreldleierskap gekonfronteer deur die feit van 'n nie-blanke volkere- en bevolkingsmeerderheid en in sy binnelandse sake deur die posisie van die Negers, het die V.S.A. 'n besondere hoë premie gaan plaas op vriendskap met haas elke nie-blanke volk. 'n Beeld moes opgebou word van die V.S.A. as antikoloniale bevryder, as kruisvaarder teen alle rassediskriminasie en as ryk en mededeelsame simpatiseerder en opbouer van die arm, nie-blanke, jong nasies. Afrika was 'n besonder ontvanklike gebied vir hierdie reklameaanbieding. Vanweë die wisselwerking van beleid t.o.v. Afrika en die behandeling van die Amerikaanse Negerbevolking en omdat die Negersteun deurslaggewend $k a n$ wees in die presidentsverkiesings, het binnelandse politieke oorwegings ' $n$ buitengewoon belangrike rol gespeel in die V.S.A. se Afrikapolitiek. Sy verskil in houding teenoor die R.S.A. en teenoor ander Afrikastate kan grotendeels ook hierheen herlei word.

\section{„Positiewe neutraliteit"}

Ontwakende Afrika het om drie belangrike redes sy aangesig na Asië gekeer. Aan Europa het, nieteenstaande alle vriendskap en hulp van daardie kant, nog altyd die stigma van kolonialisme en onderdrukking gekleef. Noord-Afrika het sterk historiese, religieuse en kulturele bande met die MiddeOoste tot so ver as Pakistan onderhou. Verder is die volke van Asië gesien as lotgenote en bondgenote: almal nie-blanke „slagoffers" van die koloniale era, bowendien arm en gekonfronteer deur die probleme van landsopbou en van identiteitshandhawing. Die Bandoengkonferensie (1955) het die nuwe Afro-Asiatiese samewerking beklink. Die solidariteit wat in die konferensienaam bely is, het veral hulle gevoel van antikolonialisme gegeld. 
Op die Accra-konferensie (1958) het die deelnemers ' $n$ beleid van onverbondenheid aanvaar, later aangedui as positiewe neutraliteit. Nkrumah het dit só omskryf: „Our policy is that of positive neutralism and non-alignment. This does not mean negative neutralism which implies the suspension of judgment, but rather the conscientious exercise of it". In die praktyk kom dit daarop neer dat die Afrikastate hulle nie gebonde ag aan een van die twee botsende wêreldblokke nie. Hulle wil vry wees om in elke geval te ondersteun of te opponeer waar hulle meen dat dit nodig en reg is. Dit stel hulle onderwyl in staat om ekonomiese en tegniese hulp van albei die blokke te ontvang mits daar geen politieke of ander voorwaardes aan die hulp verbonde is nie. As sodanig vorm hulle (saam met die onverbonde Asiate soos Indië en Pakistan) ' $n$ derde blok of krag wie se belangrikheid in die wêreldpolitiek toe- of afneem namate die spanning tussen die Vrye Weste en Kommunistiese Ooste groei of kwyn. Hierdie besondere beleid word gekenmerk deur 'n rasionele, pragmatiese bejeëning van die Weste, 'n liefde vir sy rykdomme en 'n emosionele semi-assosiasie met die Ooste.

Naas die belangstelling van Indië in Afrika-aangeleenthede, eensdeels t.g.v. sy simpatie met Indiërimmigrante in Afrika, andersyds ter wille van sy beeld as kampvegter vir nasionale vryheid, is China se bemoeienisse met en op die Afrikaanse vasteland in politieke sin die betekenisvolste. Taiwan probeer weliswaar ook kontak hou deur verlening van tegniese hulp veral wat landbouvoorligting betref, maar die implikasies en omvang van Peking se optrede is veel aktueler.

\section{China}

In 1953 maak Rooi-China sy intrede tot Afrika deur middel van die Chinese Islamse Assosiasie. In 1955 by die Bandoengkonferensie slaag hy deur die optrede van Mao Tse-toeng daarin om die Afrikadeelnemers sterk te beïndruk. Egipte was dan ook die eerste Afrikastaat wat Rooi-China erken het, gevolg deur Marokko en die Soedan. Op hierdie stadium het China 'n gunstige beeld in Afrika gehad en het groot getalle politici, studente, vakbondleiers, joernaliste en ander die land van Mao besoek. Die hoogtepunt van sy invloed is blykbaar bereik met Tsjou En-Lai se besoek aan Afrika teen die einde van 1963 en die begin van 1964. In navolging van De Gaulle 
se erkenning van Peking doen die vroeëre Franse state in Afrika insgelyks, terwyl 'n Rooi-geïnspireerde rewolusie in Zanzibar geslaagd van stapel gestuur is.

Die Peking-Moskouse konflik het sy invloed ook op China se Afrikabeleid gehad. Die twee state se weë, ook in Afrika, het geskei op die punt van beleidstoepassing. Waar die SowjetUnie as ouere en meer ervare staat bereid was tot groter soepelheid in beleidesake soos in die aanvaarding van die beleid van vreedsame koëksistensie, is die jongere Kommunistiese China onverbiddelik ingestel op handhawing van ideologiese doelstellinge, en staan sosialisering van die bevolkings deur aktiewe revolusie voorop in sy program. Die mededinging en uiteindelike botsing tussen die twee Rooi reuse het reeds in 1960 na vore gekom toe China vir Ferhat Abbas van Algerië na Peking genooi het met erkenning van die Algerynse Provisionele Regering. Rusland was op hierdie stadium besig om oor te slaan na sy vreedsame koëksistensie-beleid en na ' $n$ beleid van mindere spanning met die V.S.A. en om 'n beter verhouding met De Gaulle te verkry. China kon in hierdie omstandighede sy belangstelling in rewolusionêre aktiwiteite demonstreer en 'n sprong op Rusland wen deur hom te bestempel as ' $n$ verraaier van die nasionalistiese bevrydingsbewegings.

In hierdie situasie formuleer Peking sy Afrikabeleid. Ten einde te voorkom dat hy beleër word deur die U.S.S.R. en die V.S.A., pas China sy aggressiewe revolusionêre beleid toe in 'n poging om die bondgenootskap van die derde wêreld, met Afrika as spil, te verwerf.

In Afrika is dit die Chinese nog altyd ten gunste gereken dat hulle self ook gekleurdes is terwyl hulle snelle opgang van 'n arm, agrariese volk tot 'n staat wat kernwapens fabriseer, die Afrikane met bewondering vervul het. Maar die aard van hulle Afrikabeleid het teen die Chinese bcgin tel. Dic Zanzibar-rewolusie wat gevolg het op Tsjou En-Lai se verklaring dat daar 'n uitstekende revolusionêre situasie in Afrika bestaan, het wantroue gewek. Teen wie moet die revolusie in die Afrikastate met hulle pasverkreë vryheid gerig word anders as teen die heersende leiers? China se taktiek t.o.v. die tweede Afro-Asiatiese konferensie wat vroeg in 1965 in Algiers sou plaasvind, het China se beeld nog meer skade aangedoen. Lg. het Ben Bella voorgehou as een van die groot helde van die moderne revolusie, maar binne 24 uur nadat hy verdryf is, 
erken Tsjou En-Lai die usurpeerder, Boumedienne. In plaas van die leierskap van die Afro-Asiatiese blok deur die Algierskonferensie te verwerf, het Peking sy invloed in Afrika 'n ernstige terugslag besorg.

\section{Rusland}

Vir Lenin het die pad na Parys oor Peking en Calcutta geloop. Hy en sy opvolger het die belangrikheid van kommunistiese aansluiting by die nasionalistiese bewegings in die koloniale gebiede beklemtoon as 'n brughoof vir die sosialistiese rewolussie in daardie wêrelddele. Maar vanweë die primêre klem wat gelê is op die rol wat die werkersproletariaat in die revolusionêre proses moet speel, is die aandag in Afrika voor 1945 hoofsaaklik aan Suid-Afrika, die enigste redelik geïndustrialiseerde land, geskenk. Hier was die nie-blankes in kommunistiese oë gelyktydig arbeiderproletariaat en potensiële nasionalistiese vryheidsleër. Aansluiting by ekonomies onderontwikkelde Afrika na die Tweede Wêreldoorlog het 'n wysiging van benadering en prosedure geverg, $\mathrm{nl}$. identifikasie met die nasionalistiese bewegings sonder industriële arbeidersmassa. Die toespitsing van die Sowjet se aandag op ander Afrikastate beteken nie dat Suid-Afrika as doelwit prysgegee is nie. Inteendeel, die R.S.A. se ekonomiese ontwikkeling en sy strategiese posisie in Afrika en interkontinentaal, maak hom nog steeds ' $n$ hartstogtelike begeerde buit vir die sosialistiese rewolusie. Die beperkte omvang van kommunistiese aktiwiteite in Suid-Afrika is die gevolg van energieke en doeltreffende optrede van regering en polisie en nie verwaarlosing van die kant van die kommuniste nie.

Met die taktiek van identifikasie met nasionalistiese elemente het Rusland gehoop om die Westerse invloed in die nuwe state van Afrika te verminder. Politieke verhoudinge saam met ekonomiese hulp en handelsooreenkomste was verdere hulpmiddels in sy strewe. Daardeur is die weg meestal ook geopen vir die vestiging in hierdie lande van groot konsulêre of diplomatieke korpse wat terselfdertyd propagandasentra was. Die beleid het weliswaar nie oral daarin geslaag om hierdie lande van die V.S.A. se vriendskap te speen nie. Per slot van sake is 1 . die land van die onuitputlike dollarvoorrade wat hulle so begeer en so nodig het en terselfdertyd die land wat 'n hoë premie stel op die erkenning van die waardigheid van die nuwe leiers. Die vriendskaplike betrekkinge met die Sowjet- 
Unie het beslis ook nie beteken dat Afrika die Marxistiese ideologie in enige belangrike mate aanvaar het nie. Enkele leiers het minder of meer onder die indruk van die sosialistiese dogma gekom veral uit die dae van hulle studie of ballingskap of ten tyde van ander besoeke aan Rusland of deur kontakte met kommuniste in Londen en Parys. Van die revolusionêre taktiek en metodes het hulle trouens meer geleer en aanvaar as van die ideologie. Merendeels het die nuwe state in Rusland, soos in China en die V.S.A., handige en welkome bondgenootlike hulpbronne gewaar. Flirtasies met Rusland c.s. het dikwels ' $n$ groter afdingingskrag aan die Afrikastate verleen teenoor die Weste wat die toesegging van ekonomiese en tegniese hulp betref. Die spel is tot 'n fyn politieke afpersingsmetode ontwikkel. Daar is miskien selfs ook groter simpatieke bejeëning van Rusland, omdat hierdie gewaande nie-kolonialistiese en anti-imperialistiese staat onlangs nog dieselfde pad uit ekonomies-politieke agterlikheid geloop het tot die wêreldstatus wat dit vandag beklee. Rusland en China se rooi tapytontvangs vir haas enige persoon uit die Afrikastate en hulle ekonomiese beleggings, tegniese hulp en handelsooreenkomste wat gerig was op politieke dividende het uiteraard ook 'n belangrike sielkundige rol gespeel.

Vir Rusland was 'n Afrika-vriendskap van regstreekse betekenis vir sover as wat Wes-Afrika 'n gerieflike afspringplek kan lewer na Kuba, die "soft underbelly" van die V.S.A. Indien Rusland hier 'n brughoof kan skep, kan hy 'n bedreiging vorm vir die Amerikaans-Europese en vir die Europees-Oosterse skeepvaart om die Kaap. Op hierdie oomblik het vriendskap met Noord-Afrika deur Egipte aan die SowjetUnie 'n vasmeerplek in „warmwater", nl. die Middellandse See, verleen. Dit is die verwesenliking van 'n ou-ou Russiese droom. Vir Europa en Afrika hou dit velerlei implikasies in betreffende olievoorsiening, skeepvaart, duikboot- en vuurpylbasisse e.d.m. Met Rusland in die Middellandse See d.m.v. steunpunte in Noord-Afrika is Europa uiters kwesbaar gemaak. Alhoewel die Islam van Noord-Afrika en van die Nabye Ooste nie te versoen is met die Russiese bolsjewisme nie en aan Rusland weinig hoop bied om hierdie gebiede tot die kommunistiese leer te bekeer, moet onthou word dat vir die U.S.S.R. belangriker is om revolusionêre metodes aan ontevrede, honger en verydelde massas te leer as ideologiese oortuiging. In stede van te wag op bekering van die massas tot die Kommunisme verskaf Rus- 
siese of Russies-beïnvloede revolusionêre leiers vir die ontevrede en gegriefde groepe die kort pad na magsverkryging. In elk geval is die huidige interstaatlike vriendskap vir Rusland genoeg beloning vir sy bemoeiinge en vir sy uitgawes. Dit is terselfdertyd ' $n$ illustrasie van Rusland se gewysigde taktiek sedert 1955 , toe besef is dat openlike prediking van revolusionere aktiwiteite en van likwidasie van nasionale leiers nie die gewenste dividende oplewer nie. Voortaan sou dit wees vreedsame koëksistensie, nl. om die vriendskap met strategies geleë state so te benut dat hulle ten minste nie in die V.S.A. se hande sal speel nie. As jakkals begin om die passie te preek, beteken dit nog nie dat hy hom waarlik bekeer het nie. Juis op hierdie beleidspunt het Rusland en China se weë in Afrika uiteen begin loop.

Daar is 'n neiging in Afrika - veral uitgebuit deur China - om dit teen Rusland te hou dat hy 'n Europese en blanke land is. In die Afrikaan se gemoed bring dit voortdurend 'n element van twyfel. Tog vergoed Rusland se houding en optrede teenoor die Weste, insluitende Suid-Afrika as die groot gemeenskaplike haatobjek, sy propagandistiese ondersteuning van Afro-Asiatiese voorstelle en optrede in die V.V., sy posisie en bereidheid om ekonomiese, tegniese en militêre hulp te verleen en sy verklaarde beleid van staatsvriendskap sonder ideologiese bekeringswerk onder die volk, vir die debiete van die kleurstruikelblok.

\section{Die V.V.O.}

Die stigting van die V.V.O. op die grondslag van toekenning van 'n stem per lidland in die Algemene Vergadering het aan dic Alrikastate 'n forum gebied waarvan hulle ywerig gebruik mak. Die stemkrag van die ledestate, kwantitatief bereken in verhouding tot hulle bevolkingsterkte, gee die volgende interessante toestand:

\begin{tabular}{|c|c|c|c|}
\hline Gebiede & $\begin{array}{l}\text { Bevolking } \\
\text { (miljoen) }\end{array}$ & Stemme & $\begin{array}{c}\text { Stem per } \\
\text { Bevolkingsgetal }\end{array}$ \\
\hline Noord-Amerika & 214 & 2 & 1 per 107 milj. \\
\hline Latyns-Amerika & 243 & 24 & 1 per $10 \mathrm{milj}$ \\
\hline Europa & 444 & 26 & 1 per 17 milj. \\
\hline U.S.S.R. & 231 & 3 & 1 per 77 milj. \\
\hline Afrika & 310 & 39 & 1 per \\
\hline Asië & 2056 & 26 & 1 per 79 milj. \\
\hline Osean & 18 & 2 & 1 per \\
\hline
\end{tabular}


Dit is opmerklik hoe oneweredig die verteenwoordiging in die V.V. is, die liggaam wat so gesteld is op meerderheidsregerings, en hoeseer Afrika in 'n begunstigde posisie verkeer. Indien 'n bevredigende meting van kwalitatiewe verskille sou kon plaasvind, moet die begunstigde posisie van Afrika, LatynsAmerika en Asië in vergelyking met Europa en Noord-Amerika (Kanada en die V.S.A.) werklik in die oog spring. Hierdie struktuur en die besondere optrede van die Afrikastate in die V.V. bied aan hulle ' $n$ geleentheid om veel belangriker voor te kom as wat hulle bevolkingsgetalle, hulle ekonomiese en militêre mag, hulle volksontwikkeling en politieke stabiliteit en bekwaamheid regverdig. Hier is internasionale politieke inflasie van die ergste aard. Dit kom dan ook voor asof die vyf grotes, die permanente lede van die Veiligheidsraad, tans met 'n realistieser waardering van die rol van hierdie groep, hulle toelaat om luidrugtig stoom af te blaas in debatte in die Algemene Vergadering en om allerlei onuitvoerbare planne te beraam in 'n veelvuldigheid van komitees om dit onopsigtelik kragteloos te maak deur toepassing van die vetoreg in die Veiligheidsraad.

Tog het die opset van die V.V., die besondere gees wat geadem is deur die leierlande, hulle idealistiese gepamperlang van die nuwe state en hulle onderlinge botsinge aan die AfroAsiate geleentheid gebied om veel kwaaie gevoelens in die internasionale verhoudinge te skep. Die sending van kommissies na Trustgebiede het aanleiding gegee tot ,inciting political action" onder revolusionêre nasionalistiese groepe. Verskeie sentra in Afrika het o.a. via die V.V. die oë van die wêreld op hom gevestig: die Algerynse stryd en die Kongo-chaos, maar bowenal apartheid uit Suid-Afrika, die S.W.A.-kwessie en die Rhodesiese geskil. Die oop deure en ore vir elke Jan, Piet en Klaas om petisies in te dien of om as petisionaris te verskyn het geensins die aansien van die liggaam verhoog nie. Sy taakmag, aangewend teen die resterende bestendigheid van Tshombe se Katanga ter wille van die chaotiese Kongo, vergelyk met U Thant se oorhaastige onttrekking van die V.V.-veiligheidsmag uit die Suezgebied; sy besluite oor die S.W.A.-kwessie, konferensies oor Suid-Afrika se apartheid e.d.m. skryf altyd grotere vraagtekens oor die eerlikheid, realisme en doeltreffendheid van hierdie organisasie.

Die V.V. se Afrika-optrede openbaar terselfdertyd die bestaande diversiteit in hierdie kontinent. Want wat voorgaande 
beweer is, geld nie die hele Afrika nie. Dit onthul 'n Afrika wat in homself verdeeld is: basies as "Swart" en as „Wit" Afrika. Feitlik die hele Afrika het hom geskaar teen Portugal, Rhodesië en die R.S.A. In Afrika speel die blanke state die rol van politieke katalisator. Griewe teen hierdie drie instansies bied geleentheid vir die res om in die Statebond, op konferensies en in die V.V. op te tree, in 'n koor te sing en pogings aan te wend om druk op die ander uit te oefen. Binne Afrika is die gemeenskaplike haat en hallusinasies die voegmiddel waarmee die barste van onderlinge rusies en onenigheid toegesmeer word.

\section{Vrae en bedenkinge}

Hierdie oorsig mag nie afgesluit word met die indruk dat die aangeduide neiginge en strominge onveranderlik is nie. Daar is ' $n$ reeks onbeantwoorde vrae oor die verdere verloop van sake. Hoe lank sal die verhoudinge tussen Afrika noord en Afrika suid van die Sahara bestendig bly? Watter invloed sal die Islam op die politieke situasie uitoefen? In welke mate sal die stryd tussen Moskou en Peking in Afrika voortgesit word en met watter uitkoms? Sal die Afrikaleiers eventueel kom tot 'n realistiese waardering van die betekenis van die revolusionêre en ideologiese implikasies van hierdie bondgenote se aanwesigheid in en vriendskap met Afrika en, indien wel, wat sal hulle reaksie wees? Gaan daar 'n sterker kentering ten gunste van die Weste kom in die onverbondenheidsbeleid van Afrika? Kan en sal die Westerse moondhede waag om in opsigtelike wyse teenoor die Afrikastate op te tree in ooreenstemming met hulle werklike politieke waarde sonder om hulle in die kraal van die opposisie te jaag? In SuiderAfrika is daar 'n proses aan die gang wat moontlik en hopelik Bantoe-Afrika se houding teenoor die R.S.A. gunstig kan verander en onregstreeks 'n invloed mag hê op die Westerse verhouding tot die Republiek, Rhodesië en Portugal. Terselfdertyd mag die R.S.A. se noodsaaklike nouer skakeling met Portugal 'n struikelblok vorm vir 'n realistieser waardering van die Republiek se nasionaliteitsbeleid deur die Weste.

Tot dusver staan "Swart" en „Wit" Afrika nog grotendeels verdeeld en selfs vyandig teenoor mekaar. Hierdie verskil kom duidelik tot openbaring in die internasionale verhoudinge. Blank geregeerde Afrika het hom ondubbelsinnig geskaar teen 
die kommunistiese wêreld. Sy beleid is ingegee deur prinsipiële besware teen die Marxistiese ideologie en verder versterk deur 'n verwerping van die revolusionêre doelwitte en metodes uit daardie oord. Die besondere samestelling van die bevolking van die Portugese gebiede, Rhodesië en die R.S.A. eis 'n strenge gesags- en ordehandhawing ten einde totale chaos te voorkom. Hierdeur is die drie gebiede onvermydelik geskaar aan die kant van die Westerse moondhede in die groot politieke wêreldverdeling, sonder om daarmee te kenne te gee dat hulle alle internasionale politieke optrede van die Westerse nasies onderskryf. Die ironie van die saak is dat hulle hierdeur nie die liefde en lojaliteit van laasgenoemdes verwerf het nie. Hulle Westerse gesindheid word veelal as vanselfsprekend aanvaar. Net soos hierdie drie vir Brittanje, die V.S.A. en ander daarvan beskuldig dat hulle optrede betreffende Afrika die Rooi rewolusie bevorder, word die verwyt hulle teen die hoof geslinger dat juis hulle optrede die Weste in verleentheid stel, die nie-blanke bevolkings in die harnas jaag teen die Weste en gemene saak met die kommuniste laat maak.

In hierdie verband staan die Westerse magte voor 'n dualisme wat hulle Afrikabeleid betref net soos die Afrikastate voor 'n tweesprong staan wat hulle verhouding na buite betref. Terwyl laasgenoemdes die botsing tussen Oos en Wes probeer negeer deur ' $n$ gerasionaliseerde neutralistiese beleid wat gedurende die fase van die koue oorlog goeie dividende lewer maar haas onhoudbaar is wanneer die skietoorlog begin, dwing dit die Weste tot 'n keuse, hier en nou. Hulle is geforseer om die guns van die Afrikastate nou reeds te verwerf en te behou met die hoop dat die lelike eendjie van huidige neutralisme in geval van 'n gewapende konfrontasie mag ontpop in die swaan van ' $n$ Westerse bondgenoot. Die minste wat hulle verwag is dat neutralisme sal oorslaan in neutraliteit. Aan die realisme van sodanige verwagtinge mag ons twyfel in die lig van die gebeure tot dusver. Maar hierdie spel beteken affronte aan ware vriende ter wille van begeerde vriendskap van afsydiges. Dit impliseer en bring teweeg dat werklik betroubare en ekonomies, politiek en militêr waardevolle bondgenote onderwyl soos vyande behandel word. So word die internasionale diplomasie en politiek om Afrika ontbloot as ' $n$ immorele en riskante dobbelspel. Die enigste veilige en sekere faktor, Portugal, Rhodesië en die R.S.A., word as ver- 
handelbaar beskou vir die onsekere guns van die res. Die vlag waaronder gevaar word, is die beginselstryd vir demokrasie, vryheid en rassegelykheid; die lading is in der waarheid eie veiligheid en beskerming.

\section{BRONNE:}

American Assembly: The United States and Africa. Columbia Univ., 1958. Axelson, Eric: The partition of Africa. S.A.B.C., n.d.

Brzezinski, Z. (red.): Africa and the Communist world. Stanford, 1963. Burton, J. W. (red.): Nonalignment. London, 1966.

Coetzee, J. H.: Die Kommunistiese moondhede en Afrika. Koers, Julie '61. Coetzee, J. H.: Eenheid en verskeidenheid in Afrika. Koers, Julie/Aug. '62. Dia, M.: The African nations and world solidarity. London. 1962.

Duffy, J. en Manners, R. A.: Africa speaks. Princeton. 1961.

Encyclopaedia Britannica: Book of the year 1966: China's role in Africa. Harlow, Vincent en Chilvers, E. M. (red.): History of East Africa. Oxford, 1965.

Harrigan, Anthony: Red star over Africa. Cape Town, 1964.

Hempstone, S.: The new Africa, London, 1961.

Hovet, T. jnr.: Africa in the United Nations. London, 1963.

Ingham, K.: A history of East Africa. London. 1962.

Jansen, J. P. en Scholtz, G. D.: Afrika en Asië in 1961. S.A.U.K., s.j.

Jaquet, L. G. M.: Afrika in de wereldpolitiek in Internationale spectator, jrg. XXI, nr. 10; Febr. 1967

Kimble, George H. T.: Topical Africa. New York, 1962.

Kreinin, M. E.: Israel and Africa. New York, 1964.

Marais, M. P. e.a.: Ons vasteland, Afrika. S.A.U.K., 1962.

Nkrumah, K.: Consciencism. London, 1964.

Quigg, P. W. (red.): Africa. New York, 1964.

Rivkin, A.: Africa and the West. London, 1962.

Rubenstein, A. Z.: The Soviets in international organizations. Princeton, 1964.

Sen, C.: Against the cold war. London, 1962.

Thiam, D.: The foreign policy of African states. London, 1965.

U.S.A. Information Services: American policy statements.

Wiedner, D. L.: A history of Africa south of the Sahara. London, 1964. 